4. It has been shown, in confirmation of Oshima (1936), that various carboxylic acids inhibit $\beta$ glucuronidase preparations. Of these, citric acid inhibits the enzyme fractions with $\mathrm{pH}$ optima at 3.4 and 4.5 but has no action on the fraction with optimum at $\mathrm{pH} \mathbf{5} \cdot 2$.

5. Mucate and saccharate have been shown to exert competitive inhibition on the enzyme fractions with $\mathrm{pH}$ optima at 3.4 and $4 \cdot 5$, but to exert noncompetitive inhibition on the fraction with optimum at $\mathrm{pH} 5 \cdot 2$.
6. Suramin and heparin have been shown to be inhibitors of $\beta$-glucuronidase, the inhibition being $\mathrm{pH}$-sensitive.

7. The possible nature of the state of the separated enzymes in the original tissue is discussed, as also are the factors necessary for the inhibition of $\beta$-glucuronidase.

The expenses of this research were defrayed in part from the Rankin Fund of the University of Glasgow and by a grant from the Carnegie Trust for the Universities of Scotland which are acknowledged with grateful thanks.

\title{
REFERENCES
}

Arrhenius, S. (1889). Z. physik. Chem. 4, 226.

Becker, B. \& Friedenwald, J. S. (1949). Arch. Biochem. 22, 101.

Bernfeld, P. \& Fishman, W. H. (1950a). Arch. Biochem. 27, 475.

Bernfeld, P. \& Fishman, W. H. (1950b). Fed. Proc. 9, 150.

Durrum, E. L. (1950). J. Amer. chem. Soc. 72, 2943.

Eadie, G. S. (1942). J. biol. Chem. 146, 85.

Fishman, W. H. (1939). J. biol. Chem. 131, 225.

Jaques, L. B. (1943). Biochem. J. 37, 189.

Karunairatnam, M. C. \& Levvy, G. A. (1949). Biochem. J. 44, 599.

Kerr, L. M. H., Campbell, J. G. \& Levvy, G. A. (1949). Biochem. J. 44, 487.

Kerr, L. M. H., Graham, A. \& Levvy, G. A. (1948). Biochem. J. 42, 191.

Lineweaver, H. \& Burk, D. (1934). J. Amer. chem. Soc. 56, 658.
Michaelis, L. (1931). Biochem. Z. 234, 139.

Michaelis, L. \& Menten, M. L. (1913). Biochem. Z. 49, 333.

Mills, G. T. (1948). Biochem. J. 43, 125.

Mills, G. T. \& Paul, J. (1949). Biochem. J. 44, xxxiv.

Mills, G. T., Paul, J. \& Smith, E. E. B. (1949). 1 st Int. Congr. Biochem. Abstr. p. 597.

Mills, G. T. \& Smith, E. E. B. (1951). Biochem. J. 49, vi.

Oshima, G. (1936). J. Biochem., Tokyo, 23, 305.

Sarkar, N. K. \& Sumner, J. B. (1950). Arch. Biochem. 27, 453.

Sizer, I. W. (1943). Advanc. Enzymol. 3, 35.

Spencer, B. \& Williams, R. T. (1951). Biochem. J. 48, 537. Svensson, H. (1939). Kolloidzschr. 87, 181.

Talalay, P., Fishman, W. H. \& Huggins, C. (1946). J. biol. Chem. 166, 757.

Tiselius, A. (1937). Trans. Faraday Soc. 33, 524.

Wills, E. D. \& Wormall, A. (1950). Biochem. J. 47, 158.

\section{Studies on $\boldsymbol{\beta}$-Glucuronidase}

\section{THE INFLUENCE OF AGE, PARTIAL HEPATECTOMY AND OTHER FACTORS ON THE $\beta$-GLUCURONIDASE ACTIVITY OF RAT LIVER}

\author{
By G. T. MILLS, J. PAUL* AND EVELYN E. B. SMITH $\dagger$ \\ Biochemistry Department, University of Glasgow
}

(Received 15 April 1952)

Fishman (1940) showed that administration of borneol to dogs and menthol to mice caused a significant increase in the $\beta$-glucuronidase activity of liver, kidney and spleen but not of the testes, ovary, uterus or vagina. Fishman concluded, on the basis of these results, that the observed rise in $\beta$ glucuronidase activity was an adaptation to the excess of substrate for the assumed synthesis of glucuronides by $\beta$-glucuronidase. Fishman \& Fishman (1944) demonstrated that administration of oestrogens to mice caused an increase in uterine $\beta$-glucuronidase but had no effect on liver $\beta$ -

* Ure Research Scholar.

† Carnegie Research Scholar. glucuronidase activity. Fishman (1947) extended this work by showing that administration of doses of oestrogens within physiological limits causes a rise in the uterine $\beta$-glucuronidase activity of ovariectomized mice, the rise not being antagonized by testosterone. Fishman supposed that $\beta$-glucuronidase has a fundamental role in the physiological action of oestrogens. The assumption was made that the enzyme was specific in its action, differing for the uterus on one hand and the liver, kidney and spleen on the other. No suoh absolute specificity has been shown to exist in the hydrolytic action of $\beta$ glucuronidase, the enzyme from uterus, liver, kidney or spleen being capable of hydrolysing 
oestriol glucuronide and many other glucuronides (cf. Fishman, 1939, 1947; Kerr, Campbell \& Levvy, 1949).

Levvy, Kerr \& Campbell (1948) confirmed the effects of the administration of menthol on the $\beta$ glucuronidase activity of mouse liver and kidney, but found the spleen $\beta$-glucuronidase activity to be unaffected. These workers found menthol to cause considerable tissue damage and came to the conclusion that the elevated $\beta$-glucuronidase activity was associated with an increase in cell proliferation following injury. Other agents which cause damage in liver or kidney, e.g. chloroform, carbon tetrachloride, mercuric nitrate, phenyl arsenoxide and uranyl acetate were found by Levvy et al. (1948) to cause an elevation of $\beta$-glucuronidase activity of the organ in question. They also showed the livers, kidneys and spleens of infant mice to have a higher $\beta$-glucuronidase activity than those of adult mice, and also that the livers of adult mice 3-8 days after subtotal hepatectomy had an elevated $\beta$-glucuronidase activity. These workers concluded that an increase in the $\beta$-glucuronidase activity of an organ was found, in general, to be associated with active cellular proliferation. Kerr et al. (1949) extended this work to the effects of oestrogens on the $\beta$ glucuronidase activity of mouse uterus, with the same conclusions. Kerr, Campbell \& Levvy (1950) adduced further evidence in favour of their hypothesis, showing that colchicine, while having no action on the liver- $\beta$-glucuronidase activity of normal mice, prevented the increases usually seen following various toxic agents or partial hepatectomy, and correlated these findings with the well known effects of colchicine on cell division.

Fishman, Anlyan \& Gordon (1947) noted that many malignant, human neoplasms showed a higher $\beta$-glucuronidase activity than the normal tissue of origin. This work was extended by Fishman $\&$ Bigelow (1950) with a study of the $\beta$-glucuronidase activity of human gastro-intestinal neoplasms which confirmed their original observations, with the additional finding that involved lymph nodes also showed higher $\beta$-glucuronidase activities than uninvolved lymph nodes. The possibility that these findings only reflect a change in cell type and are not directly related to the increased cellular proliferation or cancerous changes per se may also apply to the findings of Kerr et al. (1950) on the increased $\beta$ glucuronidase activity in proliferating breast tissue in the mouse. It has been shown by Mills \& Smith (1951) that hepatoma tissue induced in rats by feeding dimethylaminoazobenzene has a lower $\beta$ glucuronidase activity than normal rat liver. Here, the distribution of cell type in the hepatoma is more nearly that of normal tissue of origin than in the cases of most other tumours. This suggests that increased $\beta$-glucuronidase activities are not necessarily an indication of active cell proliferation or cancerous changes.

The present work was undertaken in order to ascertain whether or not the hypothesis of Levvy et al. (1948), that increased $\beta$-glucuronidase activities are an indication of increased cellular proliferation in mice, applies to rats also. Use has been made in the present work of the deoxyribonucleic acid (DNA) content of tissues as an index of cell number as suggested by Davidson \& Leslie $(1950 a, b)$, in order to measure the actual degree of cellular proliferation by a direct chemical means rather than by histological examination. The results of this work indicate that, in the rat, there would appear to be no direct correlation between the $\beta$ glucuronidase activity of a tissue and the degree of cell proliferation in that tissue.

Preliminary accounts of this work have already appeared (Mills, Smith, Stary \& Leslie, 1950; Mills, 1951).

\section{METHODS}

\section{Assay of $\beta$-glucuronidase activity}

Assays by the method using phenolphthalein glucuronide (Mills, 1948; Mills, Paul \& Smith, 1953) were carried out on a $1 \%(w / v)$ homogenate of the tissue in water, prepared in the all glass homogenizer of Potter \& Elvehjem (1936). The tissue was chilled in ice before and during homogenization and the assays were carried out immediately after the preparation of the homogenate, the $\mathrm{pH}$ of assay and buffer used being indicated for each experiment. 1 glucuronidase unit $=1 \mu \mathrm{g}$. phenolphthalein liberated per hour under the conditions of assay specified.

It has been shown by Kerr \& Levvy (1951) and Walker \& Levvy $(1951 a)$ that about $40 \%$ of the $\beta$-glucuronidase of mouse-liver homogenates in water is sedimentable in high gravitational fields $(20000-25000 \mathrm{~g})$, but is brought into solution by incubation at $37^{\circ}$ in acetate buffer or by treatment with Teepol XL or Triton X-100 or disintegration in the Waring Blendor. It was claimed by Kerr \& Levvy (1951) that it was only the soluble enzyme in the original water homogenate which showed differences in the infant and adult mouse liver and before and after partial hepatectomy, the 'insoluble' enzyme remaining relatively constant. These workers showed, however, that the 'soluble' and 'insoluble' enzyme behaved identically in the hydrolysis of phenolphthalein glucuronide and concluded that there was no reason to suppose that the 'insoluble' enzyme was any less active in the tissue than the 'soluble' enzyme.

Since the large and small granules of the liver cell vary in composition and number under various conditions it was considered, in the present work, that the portion of $\beta$ glucuronidase resident in these fractions of the cell should be included in the estimate of $\beta$-glucuronidase activity. Consequently a total homogenate of liver was used.

It has been shown by Kerr \& Levvy (1951) and Walker \& Levvy $(1951 a)$ that the total $\beta$-glucuronidase activity is found in a total homogenate of mouse liver, although Walker \& Levvy (1951b) claim that this is not so for rat liver, a surface active agent such as Triton X-100 being necessary to realize full activity. In the present work it has 
been found that Triton X-100 at concentrations of $0.0075-$ $0.075 \%$ caused a $20-30 \%$ increase in the $\beta$-glucuronidase activity of mouse-liver homogenates. Ultrasonic disintegration of mouse-liver homogenates (15 min. at 2 Mcyc./ sec. at $600 \mathrm{~W}$. output; Mullard High Frequency Ultrasonic Generator, Type E. 7562) caused no increase in the $\beta$ glucuronidase activity and it would appear, therefore, that total water homogenates will give the true $\beta$-glucuronidase activity. We have found that Triton $X-100$ at the above concentrations caused a $30 \%$ activation of purified ox-liver $\beta$-glucuronidase and the use of ultrasonic disintegration is to be preferred to the use of chemical dispersing agents in view of the activating effect of Triton X-100. It has been found in this laboratory that ultrasonic disintegration causes a complete breakdown of cells, cell nuclei and cytoplasmic granules, and has no effect on the activity of $\beta$-glucuronidase in true solution.

It has been found that Triton X-100 at the above concentrations caused a variable activation of the $\beta$-glucuronidase activity of rat-liver homogenates, and in some cases there are discrepancies between the $\beta$-glucuronidase activity of such homogenates before and after ultrasonic disintegration. However, in the majority of cases, true enzymic activities as indicated by the ultrasonic-treated homogenates were given by the simple total water homogenates.

\section{Estimation of ribonucleic acid (RNA),} deoxyribonucleic acid $(D N A)$ and protein nitrogen

Estimations of RNA and DNA were carried out on $0.5 \mathrm{~g}$. samples of tissue by the method of Schmidt \& Thannhauser (1946), the phosphorus being determined by the method of Allen (1940). Protein N estimations were carried out on a sample of the alkaline digest of the tissue during the Schmidt \& Thannhauser (1946) procedure, after removal of acid-soluble phosphorus and lipid from the tissue, by the method of Ma \& Zuazaga (1942) using the Markham (1942) distillation unit.

Results are expressed as $\mu$ g. RNA phosphorus (RNAP) or DNA phosphorus (DNAP) and $\mathrm{mg}$. protein $\mathrm{N}$ per $\mathrm{g}$. fresh tissue.

\section{Estimation of liver fat}

This was carried out by the method of Channon \& Wilkinson (1935) which estimates total fatty acids and unsaponifiable matter.

\section{Treatment of animals}

All experiments recorded were carried out on male albino rats, and, with the exception of the growth experiment, animals of $200-250 \mathrm{~g}$. body weight were used. Partial hepatectomies were carried out by the method of Higgins \& Anderson (1931) under ether anaesthesia. By this procedure the median and left lateral lobes, comprising about twothirds of the total liver, are removed. The animals were kept in individual cages in a room at $22^{\circ}$ and were allowed $5 \%$ glucose as drinking fluid for the first $24 \mathrm{hr}$. in addition to free access to food. In the case of sham-operated controls, the operative procedure was the same as for partial hepatectomy, but with no interference with the liver. Bilateral adrenalectomies were carried out under ether anaesthesia, employing the dorsal approach. The animals were allowed $1 \% \mathrm{NaCl}$ solution as drinking fluid after the operation.

Carbon tetrachloride $(0.5 \mathrm{~g} . / 100 \mathrm{~g}$. body weight) was injected subcutaneously in a $40 \%(w / v)$ solution in arachis oil; controls receiving arachis oil alone in amount equivalent to the test animals on a body-weight basis.

Fatty infiltration of the liver was induced by the high fatlow protein diet F of Channon, Mills \& Platt (1943).

\section{The use of the deoxyribonucleic acid $(D N A)$ content of the liver as an index of cell number}

Boivin, Vendrely \& Vendrely (1948) showed that the DNA content of the nuclei of somatic cells of a single species was double that of the corresponding haploid cells and was relatively constant in value. These findings were confirmed by Mirsky \& Ris (1949), Vendrely \& Vendrely (1949) and Davidson, Leslie, Smellie \& Thomson (1950), who have shown that the absolute amounts of DNA per nucleus fall within a compact group for a variety of mammalian species and remain relatively constant for a given species. Davidson \& Leslie $(1950 a, b)$ have proposed, on the basis of this constancy of the DNA content of the nucleus, that the DNA content of a tissue can be used as an index of cell number. If the enzymic activity and DNA content of a tissue are determined simultaneously, the relation of the enzymic activity to the DNA content of that tissue will give an indication of the enzymic activity per cell. Heagy \& Thomson (1952) have found that the DNAP content of the adult rat-liver nucleus is $0.913 \pm 0.073$ (s.E.) $\times 10^{-6} \mu \mathrm{g}$., and that of embryonic and infant rat-liver nuclei (up to about 40 days old) is $0.76 \times 10^{-6} \mu \mathrm{g}$. This difference is explained on the basis of the distribution of diploid, tetraploid and octaploid nuclei present. In the embryonic and infant liver there is a preponderance of diploid nuclei, and in the adult rat liver a preponderance of tetraploid nuclei, octaploid nuclei being very small in number in both groups (cf. Swift, 1950; Leuchtenberger, Vendrely \& Vendrely, 1951; Harrison, 1951), the tetraploid nucleus containing twice the amount of DNA as the diploid nucleus. The ratio of diploid to tetraploid nuclei in rat liver, estimated by the DNA content of the nuclei, is relatively constant up to about 40 days old and then gradually changes to the adult level.

Heagy \& Thomson (1952) have also found that the DNA per liver cell nucleus does not alter in the adult rat under various dietary conditions, particularly on the high-fat and low-protein diet which produces fatty livers. They have found, however, that following partial hepatectomy there are some small alterations in the DNA per liver cell nucleus; these changes will be disoussed later.

\section{RESULTS}

\section{$\beta$-Glucuronidase of rat liver during maturation}

The $\beta$-glucuronidase activity and DNA concentration of rat livers were measured at various times from 16 days embryonic life until 220 days after birth, and the $\beta$-glucuronidase activities determined at $\mathrm{pH} 4.5$ in acetate buffer are shown as a function of age in Fig. 1 . It will be noted that the $\beta$-glucuronidase activity rises from low levels before birth to a maximum around 25-30 days after birth and then falls to the adult level by about 80-90 days. Interpretation of these results with reference to the growth rate of the liver is difficult, since not only is the $\beta$-glucuronidase activity varying, but so alsn are the size and composition of the liver. It was 
considered that the method of analysis likely to give the clearest picture was the allometric method first suggested by Huxley (1924) and later used by Tessier (1931) and Needham (1932) in order to study a varying part of a varying whole, where the relationship $y=b x^{k}$ is utilized. This equation in its form $\log y=\log b+k \log x$, where $b$ and $k$ are constants and $x$ and $y$ are the variables, enables us to plot log (total enzyme content of the liver) against $\log$ (liver weight) and so determine the relative rates of accumulation of $\beta$-glucuronidase activity and liver mass.

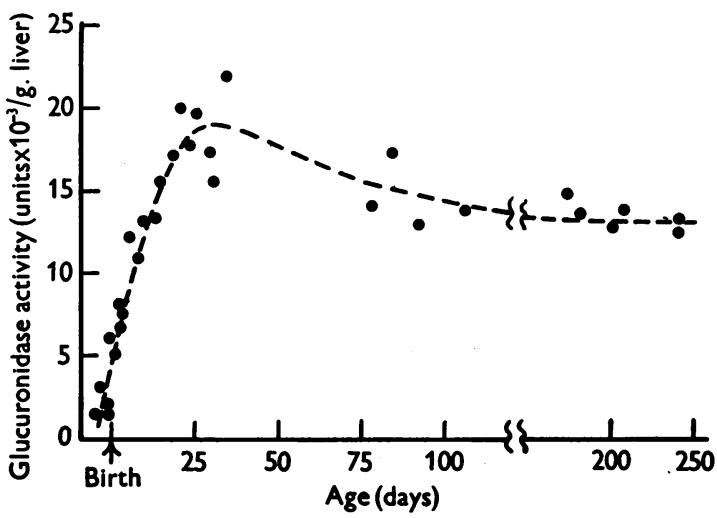

Fig. 1. The $\beta$-glucuronidase activity of male rat liver at various ages. Assay using phenolphthalein glucuronide at $\mathrm{pH} 4 \cdot 5$.

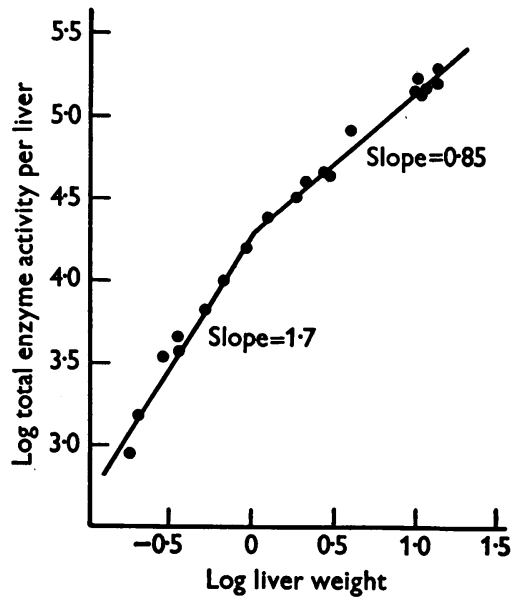

Fig. 2. Allometric plot of total $\beta$-glucuronidase activity of male rat liver against liver weight (see text p. 248).

This has been done for the $\beta$-glucuronidase activity assayed at $\mathrm{pH} \mathrm{4.5}$ and the results are presented in Fig. 2.

The most obvious feature is the two distinct phases of the accumulation graph, the early phase when $\beta$-glucuronidase activity is accumulating more rapidly than liver mass, and the later phase when glucuronidase is accumulating more slowly than liver mass, the point of transition occurring at 18 days old. While this method of analysis eliminates difficulties due to the variation in size of the liver, it does not remove the complications of the varying composition of the liver. In place of liver weight we have substituted the DNA content of the liver, since this will give us an index of the cell number in the liver, and a plot of log (total glucuronidase activity of the liver) against log (total DNA content of the liver) will give information about the rate of accumulation of glucuronidase activity relative to cell number (Fig. 3). Here again it is clear that there are two distinct phases in the

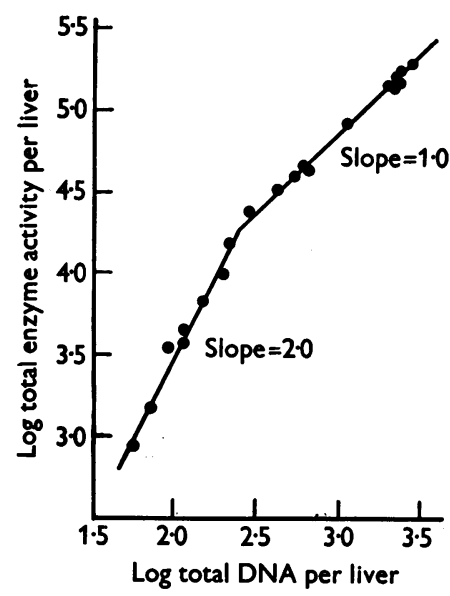

Fig. 3. Allometric plot of total $\beta$-glucuronidase activity of male rat liver against total DNA content of the liver (see text p. 248).

accumulation of $\beta$-glucuronidase activity, the early phase when the slope of the line $=2$ and the later stage when the slope $=1$. This indicates that up to a certain stage the $\beta$-glucuronidase activity is accumulating faster than the number of cells but that afterwards the accumulation rates are identical, i.e. the $\beta$-glucuronidase content per cell is constant. The time of transition is 18 days after birth. During the phase when $\beta$-glucuronidase activity related to DNA is increasing, the DNA content of the cell nucleus is constant and it is only after 40 days of age, i.e. long after the point of transition, that the DNA per nucleus begins to increase to the adult level. The period of maximum growth is around 20 days and that of maximum $\beta$-glucuronidase activity 25-30 days after birth, times when the $\beta$-glucuronidase activity per cell is constant.

It has been found that the $\beta$-glucuronidase activity assayed at the four $\mathrm{pH}$ values $3 \cdot 4,4 \cdot 5,5 \cdot 2$ and 7.0 (the optima of the four $\beta$-glucuronidase fractions found in liver by Mills \& Smith, 1952) react in an identical manner. 
The effect of partial hepatectomy on the

$\beta$-glucuronidase activity of rat liver

Seventy male adult rats were subjected to partial hepatectomy and the animals studied over a period of 10 days after the operation. Not less than six animals were examined at any one time and the

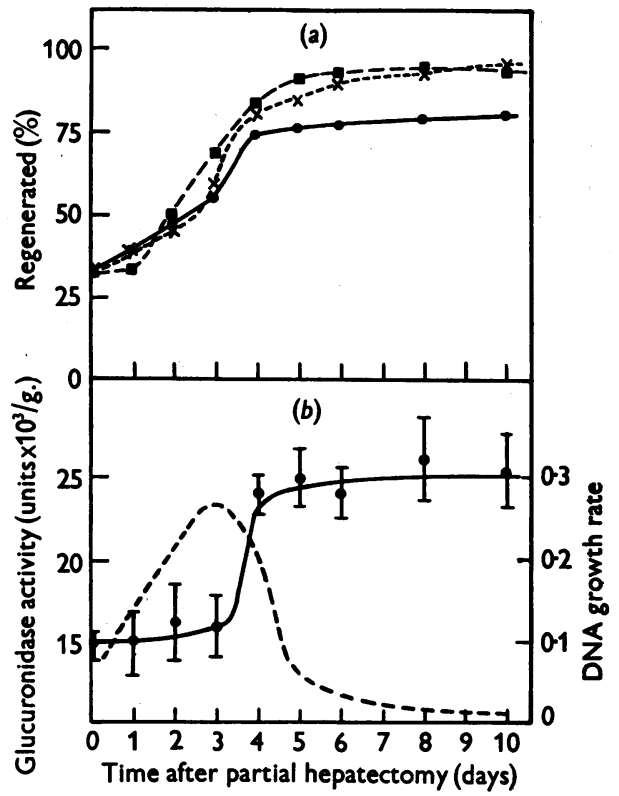

Fig. 4. The $\beta$-glucuronidase activity of male rat liver following partial hepatectomy in relation to the DNA growth rate and the percentage regeneration of liver weight, liver protein and liver DNA. (a) Percentage regeneration of liver weight, -0 ; liver protein $\mathbf{N}$, - -- ; and liver DNA, $\times \ldots . . \times$. (b) $\beta$-Glucuronidase activity with standard error of the means, $-\longrightarrow$, and the DNA growth rate, -- -, expressed as $\mathrm{d} W / W . \mathrm{d} t$ where $W=$ DNA content and $t=$ time in days.

results averaged. $\beta$-Glucuronidase activity was determined at $\mathrm{pH} 4.5$ (acetate buffer) and simultaneous analyses were made for DNA, RNA and protein $\mathrm{N}$. The results of this experiment are presented in Fig. 4.
The period of most rapid growth is over the second to fourth days after operation, at the end of which time the liver mass has reached $75 \%$, the DNA $81 \%$ and the protein $\mathrm{N} 83 \%$ of normal. It will also be seen that the rate of cell proliferation as measured by the DNA growth rate is maximal between the second and third day and thereafter declines rapidly. During this phase of rapid growth the $\beta$-glucuronidase activity remains constant and only shows a significant rise to $60-70 \%$ above normal at the fourth day, the elevated activity being maintained over the whole of the remaining period of the experiment when the cell proliferation rate is low.

When the $\beta$-glucuronidase activity and the protein $\mathrm{N}$ are correlated with DNA, it is seen (Table 1 ) that the $\beta$-glucuronidase activity/DNA ratio shows a distinct rise at 4 days which is maintained over the period of the experiment and the $\beta$-glucuronidase activity relative to protein $N$ shows a fall at 3 days which is related to an increased protein $\mathrm{N}$ per cell. This is followed by a rise at 4 days and a subsequent further rise at 8 days which is to be related to a fall in the protein $\mathbf{N}$ per cell to more normal values.

After partial hepatectomy, Heagy \& Thomson (1952) have found that the DNA per liver cell nucleus of the animals employed here rose by about $23 \%$, but returned to the pre-operative level by the fifth day. We have therefore calculated the actual $\beta$-glucuronidase activities per liver cell on the basis of the data of these workers and the results are presented in Table 1.

\section{Effect of sham operation}

The results of a sham operation are shown in Table 2, where $\beta$-glucuronidase activity ( $\mathrm{pH} 4.5$ in acetate buffer) is expressed as units/g. and as a function of DNA and protein N.

The significant finding of this experiment was the fall in $\beta$-glucuronidase activity on the first and second day after operation. While this fall is not more than $20 \%$, the differences from normal at these times are significant at a value of $P=0.02$. The $\beta$-glucuronidase was back to normal at 4 days.

Table 1. Effect of partial hepatectomy on the $\beta$-glucuronidase activity, DNA and protein $-N$ content of rat liver

\begin{tabular}{|c|c|c|c|c|}
\hline $\begin{array}{l}\text { Time after partial } \\
\text { hepatectomy } \\
\text { (days) }\end{array}$ & $\begin{array}{c}\beta \text {-Glucuronidase } \\
\text { activity/DNA } \\
\text { (units/ } / \mu \mathrm{g} . \mathrm{P} \text { ) }\end{array}$ & $\begin{array}{c}\beta \text {-Glucuronidase } \\
\text { activity/protein } \mathbf{N} \\
\text { (units/ } / \mu \mathrm{g} .)\end{array}$ & $\begin{array}{c}\text { Protein N/DNA } \\
(\mu \mathrm{g} \cdot / \mu \mathrm{g} . \mathrm{P})\end{array}$ & $\begin{array}{l}\beta \text {-Glucuronidase } \\
\text { activity/cell } \\
\left(\text { units } \times 10^{6}\right)\end{array}$ \\
\hline Before operation & 66 & 0.62 & 93 & $57 \cdot 0$ \\
\hline $\begin{array}{r}1 \\
2 \\
3 \\
4 \\
5 \\
6 \\
8 \\
10\end{array}$ & $\begin{array}{r}66 \\
70 \\
63 \\
101 \\
98 \\
90 \\
94 \\
104\end{array}$ & $\begin{array}{l}0.68 \\
0.63 \\
0.51 \\
0.87 \\
0.85 \\
0.80 \\
0.92 \\
1.01\end{array}$ & $\begin{array}{r}96 \\
83 \\
122 \\
115 \\
115 \\
115 \\
102 \\
102\end{array}$ & $\begin{array}{r}67 \cdot 0 \\
95 \cdot 3 \\
68 \cdot 6 \\
129 \cdot 0 \\
97 \cdot 0 \\
83 \cdot 0 \\
92 \cdot 0 \\
103 \cdot 0\end{array}$ \\
\hline
\end{tabular}


Table 2. $\beta$-Glucuronidase activity of rat liver in relation to other constituents after sham operation

$\begin{array}{ccc}\begin{array}{c}\text { Time after } \\ \text { operation } \\ \text { (days) }\end{array} & \begin{array}{c}\text { No. of } \\ \text { animals }\end{array} & \begin{array}{c}\beta \text {-Glucuronidase } \\ \text { activity } \\ \text { (units/g. } \pm \text { s.e.M.) }\end{array} \\ \text { Before operation } & 10 & 29290 \pm 999 \\ \text { 1 } & 5 & 22300 \pm 1500 \\ 2 & 5 & 25600 \pm 860 \\ 3 & 5 & 27280 \pm 1980 \\ 4 & 5 & 30780 \pm 3135\end{array}$

During the time of the experiment there was no change in the number of cells per liver per $100 \mathrm{~g}$. body weight as measured by the DNA content of the livers.

\section{The effect of carbon tetrachloride and arachis oil injections on rat-liver $\beta$-glucuronidase activity}

One group of rats was injected subcutaneously with carbon tetrachloride in arachis oil and an equal number of animals received arachis oil alone by the same route. The animals were examined over a period of 12 days, a minimum of five animals being examined from each group at any one time. $\beta$-Glucuronidase activity, DNA and protein concentration were determined on the livers, and the results are presented in Fig. 5.

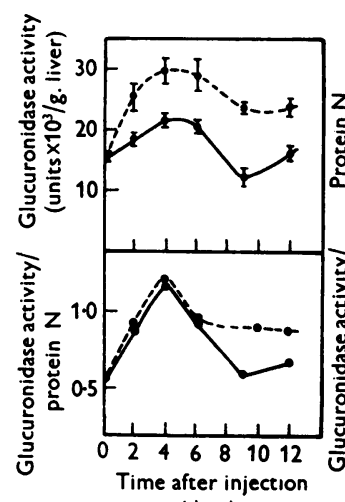

(days)

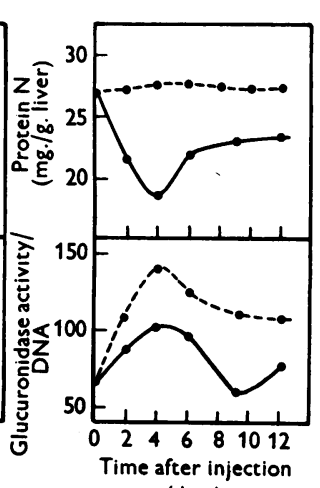

(days)
Fig. 5. The $\beta$-glucuronidase activity of male rat liver in relation to protein $\mathrm{N}$ and DNA concentration of the livers following subcutaneous injection of carbon tetrachloride in arachis oil, -10; and arachis oil alone, -...-. Ranges indicate the standard error of the means of the glucuronidase activities.

A histological examination of the livers revealed that damage by carbon tetrachloride was very marked by the second day and that repair processes first became apparent on the sixth day. No histological difference from normal could be found in the livers of the animals receiving arachis oil alone.

The striking finding in this experiment is the marked rise in liver $\beta$-glucuronidase activity following arachis oil injection. This, coupled with a

\begin{tabular}{|c|c|c|}
\hline 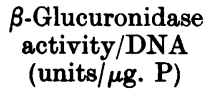 & 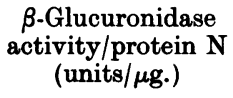 & $\begin{array}{c}\text { Protein N/DNA } \\
(\mu \mathrm{g} . / \mu \mathrm{g} . \mathrm{P})\end{array}$ \\
\hline 130 & $1 \cdot 12$ & 115 \\
\hline $\begin{array}{l}111 \\
117 \\
121 \\
111\end{array}$ & $\begin{array}{l}0.91 \\
0 \cdot 85 \\
0.93 \\
1.08\end{array}$ & $\begin{array}{l}118 \\
142 \\
131 \\
100\end{array}$ \\
\hline
\end{tabular}

constant DNA and protein concentration, indicates a great increase in $\beta$-glucuronidase activity per cell. In the case of the animals receiving carbon tetrachloride in arachis oil, the rise in $\beta$-glucuronidase activity is not so marked; in this case there is a considerable loss of liver protein. When the $\beta$ glucuronidase activity and protein $-\mathrm{N}$ concentration are compared, it will be seen from Fig. 5 that these behave relative to one another in a very similar manner in the two groups. This, coupled with the loss of protein from the livers of animals receiving carbon tetrachloride, might be taken to mean that there is an actual loss of liver $\beta$-glucuronidase activity following carbon tetrachloride, which is masked by the rise in activity caused by the arachis oil. When the repair processes are well advanced, at 6-9 days as indicated by histological examination, the general picture is returning to normal.

\section{The effect of fatty infiltration of the liver}

In view of the effects of arachis oil injections noted above and the possibility that the fatty degeneration caused by the carbon tetrachloride may influence the $\beta$-glucuronidase activity of the liver, it was decided to study the influence of the relatively simple fatty infiltration of the liver caused by a high-fat, low-protein diet. Adult male rats were therefore maintained on a high-fat, lowprotein diet, and groups of five rats examined at 5-day intervals for liver $\beta$-glucuronidase activity, DNA and protein-N concentrations. The results of this experiment are shown, along with the liver fat contents, in Table 3.

It will be seen that while there is an increase in liver $\beta$-glucuronidase activity, this is not marked, the rise being accompanied by a great increase in liver fat. The $\beta$-glucuronidase/DNA ratio, however, shows a significant increase, while the protein $\mathrm{N} /$ DNA ratio shows a decrease, producing a doubling of the $\beta$-glucuronidase/protein $\mathrm{N}$ ratio. Heagy \& Thomson (1952) have found that the DNA content of the liver cell nuclei of such animals with fatty livers is the same as that for normal adult rats. This means that not only is the $\beta$-glucuronidase activity per cell increased, but also that when the fat content of the liver has reached nearly 7 times normal, there is twice as much $\beta$-glucuronidase activity relative to protein $\mathrm{N}$ as in normal animals. 
Table 3. $\beta$-Glucuronidase activity of rat liver in relation to other constituents during feeding on fatty-liver diet

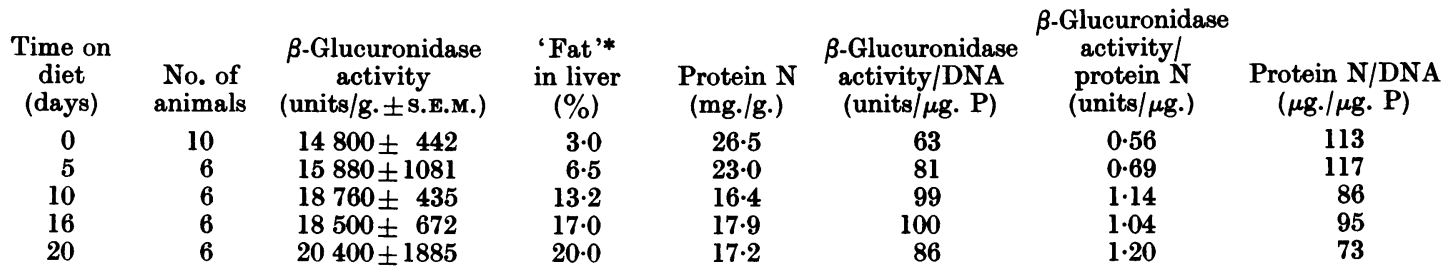

* 'Fat' = fatty acids + unsaponifiable matter.

Table 4. $\beta$-Glucuronidase activity of rat liver in relation to other constituents after adrenalectomy

$\begin{array}{cc}\begin{array}{c}\text { Time after } \\ \text { operation } \\ \text { (days) }\end{array} & \begin{array}{c}\text { No. of } \\ \text { animals }\end{array} \\ \text { Before operation } & 10 \\ 1 & 4 \\ 2 & 4 \\ 3 & 4 \\ 4 & 4\end{array}$

\section{Effects of adrenalectomy on rat-liver $\beta$-glucuronidase activity}

The response of liver $\beta$-glucuronidase activity to various toxic agents might be part of a general response to shock in the animal, particularly in the case of arachis oil injections, where no readily demonstrable changes in the liver occur. In order to test this, it was decided to investigate the part the adrenals might play in this phenomenon. Consequently, therefore, the effect of bilateral adrenalectomy on liver $\beta$-glucuronidase activity was tested. Twenty adult male rats were adrenalectomized, and examined daily in groups of five, for 4 days after operation, the results being presented in Table 4.

No significant change took place in the liver $\beta$. glucuronidase activity (acetate buffer of $\mathrm{pH} 4.5$ ), in contrast to control animals which reacted in precisely the same way as recorded in Table 2, namely, showing a fall in liver $\beta$-glucuronidase activity on the first and second day after operation. No other changes took place in the materials estimated, with the possible exception of RNA which showed a small increase.

\section{DISCUSSION}

The present findings concerning rat-liver $\beta$ glucuronidase activity relative to age are at variance with those of Levvy et al. (1948) on mice. It has been found in the present work that infant rat-liver $\beta$-glucuronidase activity is lower than that of the adult and that, as age increases, the activity rises to a maximum at around 25-30 days after birth and then declines slightly to the adult level. The period of maximum growth of rat liver is around 20 days,

$\beta$-Glucuronidase
activity/DNA
(units/ $\mu$ g. P)
130
145
122
129
115

\begin{tabular}{|c|}
\hline 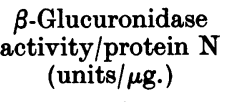 \\
\hline $1 \cdot 12$ \\
\hline $\begin{array}{l}1 \cdot 09 \\
1 \cdot 01 \\
1 \cdot 16 \\
1 \cdot 30\end{array}$ \\
\hline
\end{tabular}

Protein N/DNA ( $\mu \mathrm{g} . / \mu \mathrm{g} . \mathrm{P})$

115

134

118

111

87

a time when the $\beta$-glucuronidase activity is still rising. Using the DNA content of the liver as an index of cell number, it has been found that the $\beta$ glucuronidase per cell increases until 18 days post partum and thereafter remains constant for the rest of life. The precise reason for this sharp transition at 18 days is obscure, but it may be related to the change in endocrine balance of the animal which is known to occur around this time. It is possible that the increase in the $\beta$-glucuronidase activity of the liver cell before 18 days of age is in preparation for oestrogen metabolism. Since the present findings differ markedly from those of Levvy et al. (1948) in similar experiments on mice, it must be concluded that there is a species difference between mice and rats in the behaviour of liver $\beta$-glucuronidase activity as a function of age. This conclusion is supported by the recent findings of Walker \& Levvy (1952).

The increase in $\beta$-glucuronidase activity of rat liver seen 4 days after partial hepatectomy and maintained for at least 10 days, is similar to that seen in mice by Levvy et al. (1948) and Kerr et al. $(1949,1950)$. It is difficult to correlate this increased $\beta$-glucuronidase activity with the degree of cellular proliferation in the liver as proposed by Levvy et al. (1948). The rapid phase of growth as indicated by the DNA growth rate is at 2-4 days after operation, and at 4 days, when the $\beta$-glucuronidase activity rises, the growth rate is declining rapidly; towards the end of the experimental period, the growth rate is low while the $\beta$-glucuronidase activity remains elevated. Abercrombie \& Harkness (1951) have shown that maximum mitosis in liver occurs 1 and 2 days after partial hepatectomy. In the present work, the growth rate, as 
indicated by the DNA growth rate, agrees very closely with the results of Brues, Drury \& Brues (1936) using actual cell counts to follow the growth of liver after partial hepatectomy. This is excellent evidence for the validity of the use of DNA as an index of cell number. It is clear therefore that there is no correlation between the observed increase in $\beta$-glucuronidase activity and the increased cellular proliferation following partial hepatectomy. In the case of sham operation there is an actual decrease in $\beta$-glucuronidase activity of the liver which is not accompanied by any change in cell number of the liver on a standard body weight basis. It is difficult at present to correlate this finding, and that of the changes in liver $\beta$-glucuronidase activity following partial hepatectomy and adrenalectomy, with any known changes in the endocrinological or metabolic functions of the animal.

The very profound increase in $\beta$-glucuronidase activity of the liver seen after subcutaneous injection of arachis oil is one of the most striking findings of the present work. Such an increase was not found by Levvy et al. (1948) and it again appears as though there is some species difference, although it should be noted that Levvy et al. (1948) injected arachis oil intraperitoneally and the carbon tetrachloride in arachis oil by the subcutaneous route. The rise in liver $\beta$-glucuronidase activity produced by carbon tetrachloride in arachis oil is not so marked as in the case of arachis oil alone and in view of the fact that the $\beta$-glucuronidase/protein $N$ ratios behave in the same manner in both groups of animals, coupled with the finding that there is a protein loss only from the livers of the carbon tetrachloride group, it would appear that there is an actual loss of $\beta$-glucuronidase activity from the livers of the carbon tetrachloride animals which is masked by the rise caused by arachis oil. This may mean that the rises in $\beta$-glucuronidase activity seen after menthol administration (Fishman, 1940; Levvy et al. 1948) may actually be due to the glucuronidogenic action of menthol and not its toxic action as suggested by Levvy et al. (1948).

Some of the reported findings of Levvy et al. (1948) on mice do not always substantiate their hypothesis of the relation between $\beta$-glucuronidase activity and cellular proliferation. In some cases, e.g. carbon tetrachloride and chloroform, maximum $\beta$-glucuronidase activity corresponds with maximum tissue damage. In the case of menthol, high $\beta$-glucuronidase activities are found in the liver from 1 to 7 days after administration, with maximum tissue damage on the first day, cell division as recognized histologically being apparent only on the third day, and repair not being well advanced until 7 days after administration.

From the results presented here and from those obtained by other authors, it appears that in some circumstances, e.g. liver damage by toxic agents, liver $\beta$-glucuronidase activity rises before cellular proliferation takes place and in other cases, e.g. after partial hepatectomy, the rise in enzymic activity is after the rapid phase of cellular proliferation. The great difficulty in the earlier work was the exact determination of the time and extent of cellular proliferation. The use of a chemical method for such a determination, namely the use of the DNA content of the tissue, gives us a more accurate assessment of this problem, and enables us to be more categorical in our claim that, in the case of the rat, there is no apparent connexion between the $\beta$-glucuronidase activity of a tissue and the degree of cellular proliferation in that tissue. It would appear unlikely that cellular proliferation, a process which is probably essentially similar in most species and tissues, is to be related to changes in $\beta$-glucuronidase activity which in some respects differs markedly in two fairly similar species of animal. It is more than likely that the increased $\beta$-glucuronidase activities seen merely reflect a change in some metabolic activity of the tissue in question.

The findings of Mills \& Smith (1951) that the $\beta$ glucuronidase activity of chemically induced rat hepatoma is less than the activity of normal liver is in line with the findings recorded here, and in this case we have a rapidly proliferating tissue actually showing a lower $\beta$-glucuronidase activity than the original tissue.

An interesting finding which has arisen from the present work is that there are differences in the $\beta$ glucuronidase activities of different strains of rats. Two strains of albino rats examined had significantly different liver $\beta$-glucuronidase activities, the activities for each strain showing a reasonable degree of constancy. This situation has been shown to exist in the case of mice where Morrow, Greenspan \& Carroll $(1949,1950)$ have shown $\mathrm{C}_{3} \mathrm{H}$ mice to have a much lower $\beta$-glucuronidase activity than a number of other strains. It is interesting to recall that $\mathrm{C}_{\mathbf{3}} \mathrm{H}$ mice show a high percentage of spontaneous hepatoma (cf. Andervont \& McEleney, 1941 ; Edwards \& Dalton, 1942).

It is considered that experiments such as those recorded here and by Levvy et al. (1948) and Kerr et al. $(1949,1950)$ are not of the type which will give a direct answer to the question of the function of $\beta$-glucuronidase in the animal body. The experimental procedures bring about very profound changes in the organism and it is difficult to connect actual cause and effect. Much more information is needed concerning the actual reactions catalysed by $\beta$-glucuronidase in the animal body and the effects of various materials and procedures on these individual reactions both in vitro and in vivo, before any accurate picture of the physiological function of $\beta$-glucuronidase can be constructed. 


\section{SUMMARY}

1. It has been shown that in rats the liver $\beta$ glucuronidase activity is low at birth, rises to a maximum at around 25-30 days and then falls slightly to the adult level around 80-90 days after birth. The use of DNA as an index of cell number in the tissue, along with the allometric method of analysis, indicates that the $\beta$-glucuronidase content of the liver cell increases up to 18 days after birth and thereafter remains constant.

2. A rise in $\beta$-glucuronidase activity in rat liver to $60-70 \%$ above normal occurs 4 days after partial hepatectomy and the high level of activity persists for at least the next 6 days. An estimation of the growth rate of liver cells, using the DNA content, indicates that the period of maximum cellular proliferation is around 3 days after operation.

3. Sham operation causes a slight fall in rat-liver $\beta$-glucuronidase activity which returns to normal within 4 days. Adrenalectomy causes no alteration in rat-liver $\beta$-glucuronidase activity during the first 4 days after operation.

4. Arachis oil injection causes a profound increase in rat-liver $\beta$-glucuronidase activity, and it is concluded that the smaller rise seen after injection of carbon tetrachloride in arachis oil is to be interpreted as an actual loss of $\beta$-glucuronidase from the liver.

5. Fatty infiltration of the liver caused by a highfat, low-protein diet causes a slight rise in rat-liver $\beta$-glucuronidase activity.

6. These findings are discussed in reference to previous work on the subject and it is concluded that, in the rat, increased $\beta$-glucuronidase activities are not to be related to increased cellular proliferation as suggested by Levvy et al. (1948) for mice.

The expenses of this research were defrayed in part from the Rankin Fund of the University of Glasgow and by a grant from the Carnegie Trust for the Universities of Scotland, which are acknowledged with grateful thanks.

\section{REFERENCES}

Abercrombie, M. \& Harkness, R. D. (1951). Proc. Roy. Soc. B, 138, 544.

Allen, R. J. L. (1940). Biochem. J. 34, 858.

Andervont, H. B. \& McEleney, W. J. (1941). J. nat. Cancer Inst. 1, 737.

Boivin, A., Vendrely, R. \& Vendrely, C. (1948). C.R. Acad. Sci., Paris, 226, 1061.

Brues, A. M., Drury, D. R. \& Brues, M. C. (1936). Arch. Path. 22, 658.

Channon, H. J., Mills, G. T. \& Platt, A. P. (1943). Biochem. J. 37, 483.

Channon, H. J. \& Wilkinson, H. (1935). Biochem. J.29, 350.

Davidson, J. N. \& Leslie, I. (1950a). Nature, Lond., 165, 49.

Davidson, J. N. \& Leslie, I. (1950b). Cancer Res. 10, 587.

Davidson, J. N., Leslie, I., Smellie, R. M. S. \& Thomson, R. Y. (1950). Biochem. J. 46, xl.

Edwards, J. E. \& Dalton, A. J. (1942). J. nat. Cancer Inst. $3,19$.

Fishman, W. H. (1939). J. biol. Chem. 131, 225.

Fishman, W. H. (1940). J. biol. Chem. 136, 229.

Fishman, W. H. (1947). J. biol. Chem. 169, 7.

Fishman, W. H., Anlyan, A. J. \& Gordon, E. (1947). Cancer Res. 7, 808.

Fishman, W. H. \& Bigelow, R. (1950). J. nat. Cancer Inst. $10,1115$.

Fishman, W. H. \& Fishman, L. W. (1944). J. biol. Chem. $152,487$.

Harrison, M. F. (1951). Nature, Lond., 168, 248.

Heagy, F. \& Thomson, R. Y. (1952). Unpublished observations.

Higgins, G. M. \& Anderson, R. M. (1931). Arch. Path. 12, 186.

Huxley, J. S. (1924). . Nature, Lond., 114, 895.

Kerr, L. M. H., Campbell, J. G. \& Levvy, G. A. (1949). Biochem. J. 44, 487.
Kerr, L. M. H., Campbell, J. G. \& Levvy, G. A. (1950). Biochem. J. 46, 278.

Kerr, L. M. H. \& Levvy, G. A. (1951). Biochem. J. 48, 209.

Leuchtenberger, C., Vendrely, R. \& Vendrely, C. (1951). Proc. nat. Acad. Sci., Wash., 37, 33.

Levvy, G. A., Kerr, L. M. H. \& Campbell, J. G. (1948). Biochem. J. 42, 462.

Ma, T. S. \& Zuazaga, G. (1942). Industr. Engng Chem. (Anal.), 14, 280.

Markham, R. (1942). Biochem. J. 36, 790.

Mills, G. T. (1948). Biochem. J. 43, 125.

Mills, G. T. (1951). Biochem. J. 50, viii.

Mills, G. T., Paul, J. \& Smith, E. E. B. (1953). Biochem. J. 53, 232.

Mills, G. T. \& Smith, E. E. B. (1951). Science, 114, 690.

Mills, G. T. \& Smith, E. E. B. (1952). Unpublished observations.

Mills, G. T., Smith, E. E. B., Stary, B. \& Leslie, I. (1950). Biochem. J. 47, xlviii.

Mirsky, A. E. \& Ris, H. (1949). Nature, Lond., 163, 666.

Morrow, A. G., Greenspan, E. M. \& Carroll, D. M. (1949). $J$. nat. Cancer Inst. 10, 657.

Morrow, A. G., Greenspan, E. M. \& Carroll, D. M. (1950). J. nat. Cancer Inst. 10, 1199.

Needham, J. (1932). Nature, Lond., 130, 845.

Potter, V. R. \& Elvehjem, C. A. (1936). J. biol. Chem. 114, 495.

Schmidt, G. \& Thannhauser, S. J. (1946). J. biol. Chem. 161, 83.

Swift, H. H. (1950). Physiol. Zoöl. 23, 169.

Tessier, G. (1931). Trav. Sta. biol. Roscoff, 9, 27.

Vendrely, R. \& Vendrely, C. (1949). Experientia, 5, 327.

Walker, P. \& Levvy, G. A. (1951 a). Biochem. J. 49, 620.

Walker, P. \& Levvy, G. A. (1951 b). Biochem. J. 49, lxxvi.

Walker, P. \& Levvy, G. A. (1952). Biochem. J. 51, xx. 